\title{
To Mask or To Unmask, That Is the Question: Facemasks and Anti-Asian Violence During COVID-19
}

\author{
Hee An Choi ${ }^{1}$ (i) Othelia EunKyoung Lee ${ }^{2}$ \\ Accepted: 7 April 2021 / Published online: 16 June 2021 \\ (c) The Author(s), under exclusive licence to Springer Nature Switzerland AG 2021
}

\begin{abstract}
In the wake of COVID-19, facemasks reveal the complicated dynamics of xenophobia and violence against Asian Americans within the intersections of science, religion, and cultural diversities. This review explores what some of these complications are and how they evoke anti-Asian sentiment, introducing the different intentions of facemask usage such as hygiene, religion and criminality, and scrutiny of the uniqueness of the Asian immigrant position. Analyzing the mask-related cases against Asian immigrants in the contemporary US culture, the complex sociopolitical and cultural meanings of facemasks and their transformative functions in the context of the COVID-19 pandemic are explored. The facemask, as a symbol of power and control, re-fortifies itself to become another representation to escalate racial discriminations and violence against Asian immigrant groups. At the same time, it functions as a tool to protect us. Demonstrating these sociocultural complexities, this article asks us to give more attention to the current anti-Asian violence and the hidden struggles that Asian immigrants experience.
\end{abstract}

Keywords Facemask $\cdot$ Xenophobia $\cdot$ Asian Americans · Anti-Asian violence $\cdot$ Anti-Asian sentiment $\cdot$ Asian immigrants COVID-19 $\cdot$ Pandemic $\cdot$ Racial discrimination

In the absence of a vaccine, handwashing, social distancing, and wearing facemasks are believed to be the most effective and critical practices to slow down the spread of COVID-19 and to protect public health. Particularly, these actions are not only recommended but also now required by the law for public appearance. A recent study analyzed trends in the infection rates in three epicenters of the pandemic-Wuhan, China; Italy; and New York City, USA—comparing mitigation measures such as testing, quarantining, contact tracing, social distancing, and mandatory use of face masks (Zhang et al., 2020). Among these measures, facemasks proved to be the most effective and inexpensive practice to stop airborne transmission and person-to-person spread before the development of a vaccine.

However, during this pandemic, facemasks are often cast as the trigger of xenophobia and violence against Asian

Hee An Choi

hchoi@bu.edu

Othelia EunKyoung Lee

othelia.lee@uncc.edu

1 Practical Theology Boston University School of Theology, MA 02215 Boston, USA

2 School of Social Work, The University of North Carolina At Charlotte, Charlotte, NC 28223, USA
Americans. Asian immigrants-and their descendants who live in the US regardless of their legal and illegal statushave been targets of racism over the issue of facemasks. Why? There are complicated and conflictive sociopolitical and cultural dimensions to explain these phenomena. In fact, wearing facemasks goes beyond the current context of this COVID-19 pandemic, profoundly related to multilayers of different historical and cultural codes and meanings of racism throughout US history. Within the intersections of science, religion, and cultural diversities, facemasks reveal the complicated dynamics of racial discrimination and violence against Asian immigrants in the USA. In this process, facemasks have been actively cast as escalating this hostile anti-Asian atmosphere.

Aims of this critical review were twofold. First, analyzing the cases of anti-Asian violence over facemasks, the authors explore the sociocultural and religious implications of wearing facemasks and how this act evokes anti-Asian sentiment and violence. It introduces the different functions of facemasks, such as hygiene, religion (i.e., face-covering veils), and criminality in both USA and global contexts, and illustrates how these intentions intersect with anti-Asian violence in the context of racism. Second, the complex socio-political and cultural meanings of facemasks and their transformative functions in the context of the COVID-19 pandemic are explored in the forms 
of case studies based on news reports, journalism pieces, and personal communications.

\section{Hygiene Intention}

This article will now turn to socio-historical uses of facemasks to understand how the current anti-Asian climate arose. Wearing a surgical mask has been the common practice in medical and industrial settings. Plague doctors adopted masks as a part of costumes in the seventeenth century, yet the origin of surgical masks is unclear. In 1897, Johann von Mikulicz Radecki introduced a surgical mask, which had only one layer of gauze; but in 1898, W. Huebner encouraged surgical masks with two layers of gauze for better efficiency (Spooner, 1967). In the nineteenth century, facemasks were used to filter bad air, bacteria, and contagion (Postrel, 2020).

The common use of wearing masks in medical and general settings was adopted only in the early twentieth century after the global flu epidemic in 1918 and finally became standard for health professionals in surgical procedures and medical operating room settings in the 1920s (Tomes, 2010). The original intention to wear the mask was to protect patients with wound infections from airborne contaminants (Pyeatt, 1997). However, in the 1980s, it was proven that a surgical mask was supposed to protect (or reduce the risks to be exposed) not only patients but also the wearer from the exposure of infections that were transmitted by saliva and respiratory secretions (Mayo Clinic, 2020). Because noses and mouths are covered by the mask, wearing it also prevents direct touching of these areas, which actually causes illness. For this reason, wearing a surgical mask in medical fields became the standard and norm for prevention of diseases.

Nevertheless, wearing facemasks has not been welcomed outside of health care settings in Western industrialized countries. It is considered to be dangerous social behavior, and even stigmatized as criminally intended conduct. Because of this given social and cultural code, wearing masks in public requires certain conditions, such as a global pandemic as shown during the Spanish flu in 1918-1919. During this period, wearing masks in public was promoted "as a measure that would allow cities to function while minimizing the spread of influenza" (Tomes, 2010, p. 56). However, after the Spanish flu epidemic, wearing facemasks was discouraged and seriously criticized.

Unlike the USA and European countries, Asian countries such as China, Japan, Korea, Taiwan, Vietnam, and Thailand show a different attitude toward wearing masks in public. The facemask in public is popular and even encouraged for various reasons. It is normalized as daily practice from young to old, from women to men, and from upper class to working class. Why? The common cultural validation of wearing masks in public is to protect others from the sickness of oneself. It is understood as "collective courtesy to others" (Burgess \& Horii, 2012, p. 1184) or "protecting others from the side of solidarity" (Wong, 2020, p. 1).

Due to rapid industrialization and consequent air pollution in East Asia, wearing facemasks is understood as an ordinary practice. In addition to protecting others, it protects oneself from sickness, pollution, and other dangers beyond global epidemics. Unlike Western industrialized countries, Asians continue wearing masks even after several global epidemics have passed. Many Asians wear masks as a part of their routine practice because their daily lives are always conditioned by the great influences of industrial development and dense living situations.

To survive under these external conditions, instead of just enduring discomfort and impracticality, facemasks have become part of Asian lifestyles and spurred fashion and cultural trends, as indicated by the creation of sneaker masks (Juicestore, 2017). Beyond protection for public health, wearing facemasks carries more symbolic and psychological meaning to Asian societies. Wearing masks is an act of protecting others from any dangers that might be caused by oneself. It also allows modest Asian women to cover their bare faces and participate in social interactions in public (Burgess \& Horii, 2012). Unlike Asian countries, wearing masks in the USA context has complicated religious and cultural connotations long before this pandemic.

\section{Religious Intention}

Up until the twentieth century, covering one's head and neck had been very common fashion among Christians, Jews, and Muslims residing in the Mediterranean and the Middle East regions. From brides' veils in weddings to performance masks in theaters, and from hijab to Catholic head coverings, wearing face covers was religiously and culturally embedded in various forms of rituals and shown as part of the liturgical dress code (Ahmed, 2011). Even though many religions, including eastern religions, use face coverings as a religious practice, many current religions do not require face coverings as an absolute practice to maintain.

However, the case of hijab is different, which is one of the most controversial and conflictive debates that complicate the notion of facemasks in this cultural context. It brings not only religious interpretations of face covering and feminist critique but also political debates of national security and identity issues (Ahmed, 2011; Aspend, 2011). These political debates increased exponentially after $9 / 11$. 
Veiling is not a simple face-covering act. Rather, it is often debated as the propaganda of the colonial and postcolonial Christian sense of liberation. The matter of unveiling Muslim women is believed as an act of liberation based on the compassion of democratic Christians. In the eyes of Christians, unveiling is symbolized as a mark of advancement and liberation for women, whereas veiling is understood as the uncivilized, outdated practice of backwardness, and "Islam's inferiority and its degradation of women" (Ahmed, 2011, p. 24).

With the help of Christians, the unveiling movement claimed to liberate Muslim women from Muslim men and was intensely practiced, not only in White feminist circles but also among Muslim believers themselves between the 1940s and 1960s. In the context of the colonial West, the practice of unveiling was interpreted as demonstrating the superiority of Christianity and challenging the old traditions in the Middle East, whereas the practice of veiling was identified with the inferiority of Islam (Taramundi, 2014). Manipulating gender equality and liberation of Muslim women, and politicizing White feminism in a superior position, the colonial West criticized Islam as the uncivilized religion and Muslims as the inferior class of people. The tactics of "“ethnicization' of sexism" were used to legitimate their colonial and postcolonial violence against Muslims (Taramundi, 2014, p. 219). Hence, the unveiling movement succeeded externally and internally.

Veiling resurged in the 1970s. Under the circumstance of "the decline of Arab socialism after 1967, the expanding influence of ultra-conservative Saudi Islam and the Muslim Brotherhood, and the failure of pro-western economic policies," veils have been used to demonstrate the public presence of Islam (Aspend, 2011, p.1). Face covering becomes a self-identification and an act of defiance against the dominant culture. As growing numbers of veiling women are seen in public, veiling can be seen as an encouraging sign of powerful Islamic influence for Islamists. At the same time, it can be seen as a sign of oppression for certain groups of Muslim women, such as Egyptian women, who do not wear veils (Ahmed, 2011). Veiling becomes again the postcolonial apparatus to misconstrue women's liberation and to misconceptualize the inferiority of Islam.

After 9/11, veiling and face covering brought another layer of controversy, symbolized as a threat to national security. Muslim communities and individuals have experienced discrimination and violence at individual and structural levels. Numerous attacks and murder cases against Muslim men and women have consistently occurred. Indirect and direct tactics of systematic and political disadvantages and social isolations have been displayed and exercised. Unveiling has been re-signified as a Western Christian mission to save uncivilized people from the savage, violent religion. Conservative Christian leaders see Islam as "evil," savage, barbaric, violent, and uncivilized (Goodstein, 2003). The liberation of Muslim women is again exhibited as the subject of political debates. Some Western politicians see unveiling as their democratic project and humanitarian commitment and as their superior noble act for women's equality (Ahmed, 2011).

Veiling and unveiling debates go beyond the liberation of Muslim women. When Muslim women are used as the object of subjection for matters of the state, their issues become that of freedom of religion/speech vs. protection of public security (Bribosia \& Rorive, 2014). Whereas human rights activists try to protect individual freedoms of religion and of expression, politicians claim national security and order as their defense to limit individual freedom.

There has been growing movement globally to ban the Muslim veil. Burka bans are one example of this debate. In French and Belgian parliamentary debates, face coverings were directly identified as threats to public security by being used to commit crimes and hide weapons (National Assembly, 2010). These parliamentary debates went far beyond France and Belgium and impacted other European countries such as Italy, Spain, Netherlands, Germany, Russia, and Switzerland. The full veil became the "common enemy" of politicians and exposed their national and European western white identities, beliefs, and values in relation to racism and sexism (Bribosia \& Rorive, 2014).

Even though face covering and full body covering is not illegal in the USA, discrimination and violence against Muslims is more prevalent than in European countries. The number of assaults and violence against Muslims in the USA has consistently increased. The 127 cases against Muslims between 2015 and 2016 easily surpass the 93 cases against Muslims in 9/11 terrorists attacks (Kishi, 2017). Under the severe discrimination against Muslims in this religious cultural context, veil/face covering becomes a target of violence. By misconstruing the position of the liberation for Muslim women through veiling, these issues are further used "as moral justification for war" and violence (Ahmed, 2011, p. 195).

Veiling debates expose the intersections of voluntarism vs. individualism, sexual discrimination against women vs. the autonomy of women, the struggle with western concepts of equality, and the conflicts of Muslim identity with feminist identity and Islamic religious, cultural influence (Taramundi, 2014).

\section{Criminal Intention}

As shown in the above example of Muslims' face covering, the issue of facemasks is no longer solely a religious debate. It has been deeply entangled with issues of criminal intent, such as public security and safety. In fact, Washington, D.C. and 18 states prohibit the wearing of masks in public. Some states have complete and total bans on wearing masks, whereas other states bar wearing masks 
for the cases of crimes and deprivation of people's constitutional rights (Weiss, 2020). Let us look at the Code of Virginia as an example.

It shall be unlawful for any person over 16 years of age to, with the intent to conceal his identity, wear any mask, hood or other device whereby a substantial portion of the face is hidden or covered so as to conceal the identity of the wearer, to be or appear in any public place, or upon any private property in this Commonwealth without first having obtained from the owner or tenant thereof consent to do so in writing (Virginia Law Library, n.d., Title 18.2., Chapter 9, Article 5)

Wearing facemasks is classified under crimes and offenses. It clearly indicates that wearing facemasks is an illegal act that disturbs peace and order. Within the system of laws, it is constructed as a crime. The rationale of this law is directly related to concealing one's identity. Under the interpretation of this law, wearing any facemask in public is automatically registered as concealing one's identity to commit crimes.

Not only the USA, but also in Canada and some European countries, criminalize wearing masks as unlawful anarchist behavior. Even if people commit the same crimes, those with facemasks can be punished more severely because it is claimed that wearing masks not only intimidates others but can also lead to possible obstruction of property (Hackey, 2009). In the eyes of authorities, wearing masks can equalize peaceful protestors with armed robbers, allowing them to receive the same treatment. Authorities insist that a "no-masks policy" is for the protection of peaceful protesters in order to distinguish them from dangerous anarchists.

Ironically, the same policy is used to identify potential protesters as anarchists rather than to protect them. Nomask policies in the case of Hong Kong protests reveal the governmentality of the authority against protesters. Following the demonstration by thousands of citizens in Hong Kong on Oct. 1, 2019, Chief Executive Carrie Lam ordered a face mask ban on Oct. 4, 2019 (BBC News China, 2019). Calling on the old colonial rule, the Emergency Regulations Ordinance which bypasses all normal legislative procedures without any consensus, Lam designated all protesters who wear masks as anarchists and criminals. Within 3 days, thousands of Hong Kong protesters were turned into criminals under this law. Wearing masks protects the identities of protesters whereas nomask policies protect the identities of the current authorities and lawmakers in Hong Kong.
Fear of wearing masks in the USA is also deeply related to issues of protest. Prohibition on wearing masks first appeared in the form of law around 1845 after farmers in the Hudson Valley wore disguises and attacked police (Livni, 2020). From the start, anti-mask policies were created to help police identify protesters. Ironically, almost all states adopt this anti-mask policy to condemn Ku Klux Klan (KKK) masks, but, until recently, the policy has been exercised more against protesters who fight for racial justice (Weiss, 2020).

In the current COVID-19 pandemic, wearing masks is still compared to and overlapped with the image of KKK masks. Current incidents of a Norman police officer (Fife, 2020), a man in San Diego County (O'Kane, 2020), a man in California (Elliott, 2020), and many other cases reflect the tragic legacy of the KKK. Unfortunately, wearing facemasks is often interpreted as denying or challenging authority from both protesters and authorities. It is signified as a simultaneous threat to the current sociopolitical religious construction and a shield of individual freedom and liberation. Wearing masks is understood both as committing crimes in the eyes of authorities and protecting freedom and liberation in the eyes of the protesters. These are the current understandings that may negatively affect Asian American communities.

\section{Anti-Asian Violence Through Facemasks}

The racist belief that Asians carry disease goes back centuries. In the nineteenth century, Asian immigrants were exploited for their labor and were villainized as the "Yellow Peril." White labor unions argued for an immigration ban by claiming that "Chinese" disease strains were more harmful than those carried by White people (Hsu, 2016). Such anti-Asian sentiment led to the Chinese Exclusion Act of 1882, which was the first racialbased exclusion law in the US history and lasted for 6 decades. The image of "forever foreigner" was not just the cultural image that was shown in stereotypes. It was the actual reality that Asian immigrants had to live under this discriminative policy for a long time. They were legally asked to be forever foreigners. This policy still continues to lock Asian immigrants in the image of forever foreigner until now (Choi, 2015; Choi, 2020). Japanese American internment was another example of this harmful effect. World War II escorted in the internment of Japanese Americans into camps under Executive Order 9066 (Lee, 2015).

The Immigration and Naturalization Act of 1965 abolished former anti-Asian immigration laws and prioritized skilled workers (Hsu, 2016). During this period the "model minority" myth was spreading. This idea posited that Asian Americans were more successful than other ethnic minorities because of hard work, education, and inherently law-abiding natures. In 
retrospect, the model minority myth has been a tool to protect White power and privilege and defend White superiority against Black power movements and racial justice movements (Lee, 2015). Not only does such a myth create a monolithic identity for Asian Americans and render their struggles invisible, but it also drives a wedge between them and other communities of color, primarily African Americans.

The anti-Asian sentiment, on the basis of claims that these groups bring disease, has continued over times of societal unrest. However, the recent and rapid uptick in xenophobic behaviors ranging from micro-aggressions to overt aggressive and threatening behavior has been concerning (Le et al., 2020). Since the outbreak of the pandemic, people of Asian descent have been targets of derogatory language in media reports and statements by politicians as well as on social media platforms, where hate speech related to COVID-19 also appears to have spread virally. Former President Donald Trump, who has referred to COVID-19 as the "Chinese virus" and the "kung flu," has helped normalize anti-Asian xenophobia, stoking public hysteria and racist attacks.

Right after announcing the COVID-19 pandemic, Asian Americans Advancing Justice reported approximately 2000 incidents of violence against Asian immigrants in 45 states and Washington, D.C. (CBSN, 2020). A new Center for Public Integrity/Ipsos Poll informed that 3 in 10 Americans blame the Chinese, and 32\% of Americans and 60\% of Asian Americans witnessed blaming Asian immigrants for the cause of the virus (Ipsos, 2020; Miller, 2020). The US society seeks to blame the victims for the cause of this virus and cast Asian immigrants as the scapegoat for this natural disaster. Incidents of anti-Asian racism include discrimination, racial slurs, and violent attacks (e. g., being spat on, having an object thrown at a person of Asian descent, etc.), remain unreported to the authorities. Some victims have been harassed in public or barred from businesses or transportation, yelled at in supermarkets, accused of "bringing coronavirus" to the USA, or refused transport in car share services. Small businesses run by Asian Americans have reported coronavirus-related harassment and acts of vandalism (Miller, 2020).

In the intersections of hygienic, religious, and criminal intentions, the COVID-19 pandemic brings more sociopolitical complications of wearing masks, especially to Asian immigrants in the USA. Unlike other Asian countries where most citizens followed the rules and adopted this new custom within a few weeks of the pandemic, the USA has had a hard time adopting the rules to wear masks in public. Cultivating prejudices of religious and criminal intentionality, and interpreting pro-mask policies as a threat to individual freedom, political leaders did not encourage people to wear masks, especially at the beginning of the COVID-19 pandemic. As a result, it has become much harder for US communities to embrace all the restrictive measures that slow down the spread of the virus, such as sheltering in place and wearing masks.

Favorable attitudes toward wearing masks are transmitted to Asian immigrants, especially the first-generation immigrants in the USA. Through transnational influences and from individual personal experiences, Asian immigrants are less resistant to wear masks in public. An Asian American nurse who works in critical care was very concerned that her colleagues do not take extra precaution, "No wonder this virus spread so fast. I wear two masks and a face shield. None of my skin is exposed, particularly when I treat a COVID patient" ( $\mathrm{S}$. Ma, personal communication, June 6, 2020). Another Asian American social worker echoed,

\section{It was several months after 9/11. I got strip-searched at the airport for the first time in my life. I remember how infuriated I was. Then I was reminded that it is for public safety. All Americans had to adapt to this new custom. Better safe than sorry. I do not understand why it is so difficult for some Americans to adapt to yet another custom to wear masks for public health and safety. Wearing masks should not be a politicized issue when over hundred thousand lives were lost (A. Lee, personal communication, May 30, 2020).}

Even wearing a facemask, an act associated with Asians before it was recommended in the USA, could be enough to provoke an attack. In spite of their awareness of hygiene concerns and cultural practices, some hesitated to wear masks in public amid reports of hate crimes and racism toward Asian Americans who wore masks. As anti-facemask sentiment was raised along with anti-Asian sentiment, xenophobia and violence against Asian immigrants immediately started to occur in various forms.

The Stevens Point grocery store incident is a good example of non-Asian Americans reactions to Asian immigrants wearing masks. According to police, a 57-year-old man verbally harassed Asian Americans in a Stevens Point grocery store. He defended himself by saying that he made a false connection between Chinese in China, the place of the virus's origin, and Chinese in their own community (Mentzer, 2020). According to a statement from the Stevens Point Police Department, Asian American customers were harassed on the basis of their race.

The act of Asians' wearing masks is understood as the act of hiding Asian identities and escaping blame. As 3 out of 10 Americans still blame Chinese people for the cause of COVID-19 (Ipsos, 2020; Miller, 2020), these Americans want to identify Asian immigrants as the "original sinners" who brought disaster to them. For them, wearing masks prevents this identifying process and postpones punishment, akin to avoidance and denial of the committed crimes.

However, their intention to unmask Asian immigrants is neither distinguishing other Asian immigrants from Chinese 
immigrants nor identifying Chinese immigrants specifically. Rather, the purpose of this unmasking process is to classify various Asian immigrants into one single race category, erasing different Asian national identities and making all Asian immigrants "the Other" (Choi, 2015). By marking Asian immigrants as the Other, the common enemy, racially divided U.S. society can become united. It justifies the violence against Asian immigrants as self-defense, namely, a pathological logic of racism.

Here is another similar example to explain this logic. An alleged victim, a Chinese woman in the New York City subway who wore a facemask, was physically assaulted with kicking and punching. She was called "diseased" (Li, 2020). Locating wearing masks as the cause of violence, these hate crimes reveal the pathological minds of the abusers and their deeply rooted images of Asian immigrants being forever foreigners.

Asian immigrants are seldom considered to belong to US society as full members, being treated as permanent guests who need to go back to their Asian countries (Choi, 2015). In the intersections of hygienic, religious, and criminal intentions, the practice of Asians wearing masks extends the image of Asian immigrants as permanent guests to another image, the dangerous foreigners who carry diseases and kill natives. They are perceived as the dangerous foreign enemies under this pathological logic. Fearing foreignness, anti-Asian violence is explained as the personal patriotic act to protect US society from dangerous foreigners. This mentality supports no-mask policies, not only for public security but also for stigmatizing the images of Asian immigrants as "forever foreigners" in a repeated manner.

However, anti-mask sentiments are not the only threat that Asian immigrants face. Ironically, pro-mask policies are also used against them at the same time. There is another incident in New York City to show this point. "The attacker-who pulled down her own mask during the tirade-confronted the 36-year old victim on a southbound F train at the Delancey St. station about 7:45 a.m. Friday, yelling that she wasn't wearing the mask properly, police said. The bossy rider then screamed at the victim, 'You f--king Chinese don't speak English! Go back to China!' cops said" (Annese, 2020). In this attack, wearing masks improperly was used as the cause of anti-Asian violence. Condemning Asian immigrants spreading diseases, the report discloses that Asian immigrants are under the obligation to wear masks perfectly. In this context, the demand of wearing masks perfectly means not showing Asian immigrant presence. It implicates the complete removal of Asian presence in public and private domains (Choi, 2020). As no-mask policies are used to identify Asian presence for blame and punishment, pro-mask policies are adopted to erase the presence of Asian immigrants or expel them. Asian immigrants are forced to live in this dilemma. Therefore, wearing or not wearing masks for Asian immigrants is not a real issue. The real issue is intolerance of differences that US history repeatedly shows.

\section{Controlling Facemask as the Interpellation of Racism: White Power and Privilege}

Anti-Asian sentiment, born from this intolerance of differences, is not a new phenomenon. It has been deeply embedded from the beginning of Asian immigrant lives in the USA. During this COVID-19 pandemic, this embedded racism has been exposed on a deeper level. Using the masks as the interpellation of US racism against Asian immigrants, shows how these immigrants are perceived and where they stand in the context of racism. Beyond hygienic, political, cultural intentions, the mask transmits more complicated racial conflicts to Asian immigrants. Controlling the wearing of masks for Asian immigrants, discloses US white power and privilege.

Some White men claim that wearing masks is not their obligation. It is not their practice to perform. They believe that wearing masks violates their individual rights and compromises their superior position as White men. A Michigan protest exhibits this belief. Inspired by Trump's tweet to "Liberate Michigan!" some adults gathered at the state capital to demonstrate their constitutional civil rights (Bouie, 2020), the majority of whom were White men. They were armed with machine guns and chose not to wear facemasks and exercise social distancing.

This belief is not just exhibited in a political demonstration. CNN news shows how this belief is deeply embedded in ordinary White male culture. A White man without a mask on a crowded beach over the Memorial Day weekend never felt the need to wear masks, "My wife and kids wear [masks] but not me," he said (CNN, 2020). His unspoken expression appeared that wearing it was not congruent with his masculine values.

This reaction mirrors representation in the White House. In response to questions of why he did not wear masks during a press conference, Trump said "people who serve me can wear mask. But not the king... It is not kingly" (Allen, 2020). In a tweet on 25 May 2020, he also ridiculed his political opponent for wearing a mask at the Memorial Day tribute. In another press conference, he was asked by an Asian American female reporter why he claimed that the USA is performing better than other countries in terms of COVID-19 testing (Gabbatt \& Smith, 2020). His response was "ask China." When the reporter pointed out racism in his remarks, he abruptly left the conference room.

From ordinary White men to White male protesters and political leaders, wearing masks is understood as the subject for "others" to perform and practice. It is not their responsibility to wear masks. Rather, anti-mask wearing attitudes were demonstrated as the proof of White superiority over other races. Breaking into the "People's House" on January 6,2021 is one of the most explicit examples of this white superiority. The entire world was appalled to witness crowds of mobs (mostly White men without facemasks) breaking into the Capital so easily. This incident clearly represented 
the irony of White privilege as to how law reinforcement was tolerant with right-wing protesters (New York Times, 2021).

This protest should be condemned as an insurrection and threat to democracy. Unfortunately, White superiority is not just a current White cultural belief. The ideology of White superiority based on White power and privilege has been repeatedly reinvented and resurged in colonial and postcolonial sociopolitical and cultural constructions in the form of racism, sexism, heterosexism, classism, and other discriminative ideologies (Choi, 2020). From religious favoritism to social and scientific research, White superiority is presented as Truth. By not wearing masks and controlling masks on others, White sociopolitical construction tries to demonstrate White power and superiority over other ethnic people, specifically using Asian immigrants as the scapegoats.

However, Asian immigrants have pivoted from the position of scapegoat. At the wake of George Floyd's death, their experience of discrimination created solidarity with the Black Lives Matter movement. Even though Asian Americans do not experience racism in the exact same way that Africans/African Americans do, they experience racism daily and differently. From this experience, they recognize the importance and need for solidarity with African/African American groups. Both Asian Americans/immigrants and Afrians/African Americans are concerned about the systems and institutions in the USA that create conditions where Asians are seen as forever foreigners and Black people are not granted basic humanity and rights.

Letters for Black Lives, an organization that provides multi-lingual resources to help people talk about Black Lives Matter with their families, was started by young Asian Americans in 2016. The group has created resources designed to educate and inform Asian Americans about how their history has intersected with Black history Ignite Young Asian People Power (2020). For example, "Ktown for Black Lives" points to the growing momentum among L.A.-based Korean and Asian American organizers standing in solidarity with Black Lives Matter and calling for Black liberation (Tso, 2020). Instead of accepting the position of scapegoat, they actively resist white power and control and create solidarity with others.

\section{Discussion}

In the past decades, global health epidemics and pandemics have grown to encompass air pollution, which is especially concentrated in rapidly industrializing cities across Asia. Facemasks have become must-have items in Asia for people's physical survival. City dwellers have come to adopt surgical masks as shields against dangerous airborne particulate matter. However, wearing masks in the USA has a different connotation and stigma. In the sociopolitical cultural context of the USA, facemasks in public are automatically registered as concealing one's identity from being sick, being criminals, being Muslims, or being Asians.

During the COVID-19 pandemic, wearing masks has brought more serious complications of racism, especially against Asian immigrants. As the cases based on two interviews and ten journalism pieces illustrate, facemasks are often cast as the cause of violence against Asian immigrants. Masks are understood as an indicator of covering racial Asian identities and avoiding blame in public, as well as being used as a representation for the complete erasure of the presence of Asian immigrants simultaneously. Even though no-mask policies were created to uncover the identities of KKK members, they have far more consistently functioned as a tool to uncover the identities of protesters. Despite the fact that people wear masks for different reasons of health, faith, peaceful protests for justice, and fashion, and to keep and protect their identities, they are always kept under suspicion for their criminal intents.

This critical review and commentary demonstrated the complex sociopolitical and cultural construction of facemasks and their transformative functions in the context of the COVID-19 pandemic. Throughout US history, facemasks have been one of the most controversial and dangerous interpellations that bring us into exploring the complicated stratum of sociopolitical cultural racial reality. Wearing masks is not the will of the wearers in the USA. In the intersections of various intentions, controlling masks is a demonstration of how to protect "our" privileges from the other. Asian immigrants as "the other" are used as the subject of control by wearing or removing masks from their own faces.

In the midst of COVID-19, it is important to note that the original intention of Asians wearing the mask started not from protecting oneself but for protecting others first. When one feels sick, this person wears a mask to protect others from the illness that he/she/they suffer. Under the cultural influences of communality and moral ethics, considering others and community before individuals is one of the most important cultural beliefs that Asians and Asian immigrants have learned and exercised. However, their intention is disdained and dismissed. By wearing or not wearing masks, the complete erasure of their presence is demanded.

Although the violence against Asian communities did not precipitate national awareness of racism committed against them, the Black Lives Matter movement has reignited national awareness of systemic and institutional racism in the USA. This activism impacted a policy. In September 2020, the US House of Representatives passed a resolution 243-164 condemning racism against Asian-Americans tied to the COVID-19 pandemic. More proactive social policy like this should be developed to prevent further racist behaviors.

With change of political leadership in the USA, a national facemask mandate policy in the first 100 days of the new 
administration has been on the table. As of this writing, following 11 months into the global pandemic, this reasonable proposal has continued generating much controversy nationwide. It is expected that this inconvenient policy may be implemented proactively to promote common good and public health. Nevertheless, national debates on constitutional rights vs. protection for public health remain to be resolved in these divisive political climates.

It was proven that facemasks become an evidence-based practice in the absence of a vaccine. Unfortunately, such just and effective health behaviors failed to get buy-in by many stakeholders and have proven to be unsustainable. A daunting task ahead of us is how to reframe facemasks as "a perfect learning opportunity of balancing individual freedom and social responsibility" (Lee, 2021, p. 244). Future research should examine further the factors preventing and facilitating health behaviors such as wearing facemasks and taking vaccines in relation to intersections of race and class. In this ever-changing world, it is especially critical to examine racial disparities and cultural differences about certain health-promoting behaviors so that healthcare providers can develop effective strategies to encourage healthy behaviors.

\section{References}

Ahmed, L. (2011). A quiet revolution: the veil's resurgence, from Middle East to America. Yale University Press.

Allen, N. (2020). Why won't Donald Trump wear a face mask in public? The Telegraph. https://www.telegraph.co.uk/news/2020/05/ 22/wont-donald-trump-wear-face-mask-public/

Annese, J. (2020). Women screams anti-Chinese remarks at Manhattan commuter, slaps her phone away. New York Daily News. https:// www.nydailynews.com/coronavirus/ny-coronavirus-anti-asianstatements-mask-assault-20200517-6g2o6zzikrhedl3z7sbrrfl7bastory.html

Aspend, R. (2011). A quite revolution by Leila Ahmed-review. The Guardian. https://www.theguardian.com/books/2011/may/20/quietrevolution-leila-ahmed-review

Bouie, J. (2020, May 8). Anti-lockdown protesters have a twisted conception of liberty. New York Times. https://www.nytimes.com/ 2020/05/08/opinion/sunday/anti-lockdown-protesters.html

Bribosia, E. \& Rorive, I. (2014). Insider perspectives and the human rights debate on face veil bans. In: E. Brems (ed), The Experiences of Face Veil Wearers in Europe and the Law. (1st ed, pp.167-179). Cambridge University Press.

British Broadcasting Company News China. (2019, October 4). Hong Kong: Face mask ban prompts thousands to protest. https://www. bbc.com/news/world-asia-china-49939173

Burgess, A., \& Horii, M. (2012). Risk, ritual and health responsibilisation: Japan's 'safety blanket' of surgical face mask-wearing. Sociology of Health and Illness, 34(8), 1184-1198. https://doi. org/10.1111/j.1467-9566.2012.01466.x

Cable News Network. (2020). Americans flock to beaches for holiday weekend. https://edition.cnn.com/videos/us/2020/05/25/memorialday-beaches-coronavirus-social-distancing-flores-vpx.cnn

CBS News Los Angeles. (2020). Officials: Hate crimes against Asian Americans spike in wake of coronavirus pandemic. https:// losangeles.cbslocal.com/2020/05/13/coronavirus-hate-crimes-spikeasian-americans/
Choi, H. A. (2015). A postcolonial self: Korean immigrant theology and church. State University of New York Press.

Choi, H. A. (2020). A postcolonial leadership: Asian immigrant Christian leadership and its challenges. State Univesity of New York Press.

Elliott, J. K. (2020). No charges for man who wore KKK hood to store as coronavirus mask in California. Global News. https:// globalnews.ca/news/6938336/coronavirus-kkk-hood-charges/

Fife, A. (2020). Norman police officer under investigation for comparing use of facial masks to KKK scene in 'Django Unchained University'. Oudaily. http://www.oudaily.com/coronavirus/norman-policeofficer-under-investigation-for-comparing-use-of-facial-masks-tokkk-scene-in/article_deeabf9a-99fb-11ea-9fb6-3b10e2329100.html

Gabbatt, A., \& Smith, D. (2020). Trump accused of racism after clash with Asian American reporter. The Guardian. https:// www.theguardian.com/world/2020/may/12/trump-weijia-jiangchina-attack-racism-accusations

Goodstein, L. (2003). Seeing Islam as 'evil' faith, evangelicals seek converts. New York Times. https://www.nytimes.com/2003/05/ 27/us/seeing-islam-as-evil-faith-evangelicals-seek-converts.html

Hackey, J. P. (2009). Stifling dissent through creative use of the criminal law: The charge of wearing a mask with intent. Criminal Law Quarterly, 55, 120-133

Hsu, M. (2016). Asian American history: A very short introduction. Oxford University Press.

Ignite Young Asian People Power. (2020). Resources for BLM movement. Asian American Organizing Project. http://aaopmn.org/ resources/

Ipsos. (2020). New center for Public Integrity/Ipsos poll finds most Americans say the coronavirus pandemic is a natural disaster: Three in ten Americans blame China or Chinese people for the pandemic. https://www.ipsos.com/en-us/news-polls/center-forpublic-integrity-poll-2020

Juicestore. (2017). A Day with Zhijun Wang. https://juicestore.com/ blogs/editorial/a-day-with-zhijun-wang

Kishi, K. (2017). Anti-Muslim assaults exceed 2001 total. FactTank: News in the Numbers, Pew Research Center. https://www.pewresearch.org/facttank/2017/11/15/assaults-against-muslims-in-u-s-surpass-2001-level

Le, T. K., Cha, L., Han, H. R., \& Tseng, W. (2020). Anti-Asian xenophobia and Asian American COVID-19 disparities. American Journal of Public Health, 110(9), 1371-1373. https://doi.org/10. 2105/AJPH.2020.305846

Lee, E. (2015). The making of Asian America: A history. Simon \& Schuster.

Lee, O. E. (2021). Regraming facemasks as tools to balance individualism and social responsibility. Qualitative Social Work, 20, 240 246. https://doi.org/10.1177/1473325020973318

Li, D. K. (2020). Coronavirus hate attack: woman in facemask allegedly assaulted by man who calls her 'diseased'. NBC News. https://www.nbcnews.com/news/us-news/coronavirus-hate-attackwoman-face-mask-allegedly-assaulted-man-who-n1130671

Livni, L. (2020). Coronavirus pits anti-mask laws against public health. Quartz. https://qz.com/1837586/coronavirus-pits-anti-mask-lawsagainst-public-health/

Mayo Clinic. (2020). COVID 19-how much protection so dace masks offer? https://www.mayoclinic.org/diseases-conditions/coronavirus/in-depth/coronavirus-mask/art-20485449

Mentzer, B. (2020). Police: Wisconsin man harassed Asian Americans for wearing masks at grocery store police recommend hate crime charges against 57-Year-Old Stevens Point man. Wisconsin Public Radio. https://www.wpr.org/police-wisconsin-man-harassed-asianamericans-wearing-masks-grocery-store

Miller, J. R. (2020). 32 percent of Americans have seen coronavirus bias against Asians: Poll. New York Post. https://nypost.com/ 2020/04/28/32-percent-of-americans-have-seen-coronavirusbias-against-asians/ 
National Assembly. (2010). Information Report 178; Parliamentary Documents of the House of Representatives, Session 2009-10, Report. Doc No. 52 2289/005, 8 and 16. Author.

New York Times. (2021). Today's Rampage at the capitol, as it happened. https://www.nytimes.com/live/2021/01/06/us/washingtondc-protests

O'Kane, C. (2020). A San Diego man wore a KKK hood as a face mask: Officials say they have no grounds to charge him. CBS News. https:// www.cbsnews.com/news/ku-klux-klan-hood-face-mask-san-diegono-charges/

Postrel, V. (2020). Pandemics come and go, but medical masks are eternal. Bloomberg Opinion. https://www.bloomberg.com/opinion/articles/ 2020-04-10/medical-face-masks-an-illustrated-history

Pyeatt, P. L. (1997). Surgical masks. AORN Journal, 65, 18-22

Spooner, J. L. (1967). History of surgical face masks: The myths, the masks, and the men and women and behind them. AORN Journal, $5,76-81$

Taramundi, D. M. (2014). Women's oppression and face-veil bans: A feminist assessment. In E. Brems (ed.), The experiences of face veil wearers in Europe and the law (pp: 218-227). Cambridge University Press.

Tomes, N. (2010). Destroyers and teacher: Managing the masses during the 1918-1919 influenza pandemic. Public Health Reports, 125(3), 48-62. https://doi.org/10.1177/00333549101250S308
Tso, P. (2020). L.A. activists recall lessons of 1992 uprising in new efforts on Asian-Black relations. Korea town black life matter. NBC News. https://www.nbcnews.com/news/asian-america/1activists-grapple-legacy-1992-uprising-asian-black-relationsn1233087

Virginia Law Library. (n. d.). Code of Virginia. https://law.lis.virginia.gov/ vacode/title18.2/

Weiss, D. C. (2020). Do anti-mask laws make us all criminals? Lawyer who challenged this law sees issues. ABA Journal. https://www. abajournal.com/news/article/do-anti-mask-laws-make-us-allcriminals-lawyer-who-challenged-this-law-sees-issues

Wong, T. (2020). Corona 19: Countries with and without masks. $B B C$ News Korea. https://translate.google.com/translate?hl=en\&sl= ko\&u=https://www.bbc.com/korean/news-52044990\&prev= search

Zhang, R., Li, Y., Zhang, A. L., Wang, Y., \& Molina, M. J. (2020). Identifying airborne transmission as the dominant route for the spread of COVID-19. Proceedings of the National Academy of Sciences. https://doi.org/10.1073/pnas.2009637117

Publisher's Note Springer Nature remains neutral with regard to jurisdictional claims in published maps and institutional affiliations. 